\title{
The Influence of Single and Double Steel Plate Hardness on Fracture Behavior after Ballistic Impact
}

\author{
Helmy Purwanto ${ }^{1 *}$, Rudy Soenoko², Anindito Purnowidodo², Agus Suprapto³ \\ 1 Department of Mechanical Engineering, Faculty of Engineering, Universitas Wahid Hasyim, 50236 Semarang, Indonesia \\ 2 Department of Mechanical Engineering, Faculty of Engineering, Brawijaya University, 65145 Malang, Indonesia \\ ${ }^{3}$ Department of Mechanical Engineering, Faculty of Engineering, University of Merdeka Malang, 65145 Malang, Indonesia \\ * Corresponding author, e-mail: helmypurwanto@unwahas.ac.id
}

Received: 04 December 2017, Accepted: 07 June 2020, Published online: 17 July 2020

\begin{abstract}
This study aims to determine the ballistic characteristics of the two steel plates with different hardness levels and mix in the form of layered in non-permanent constructions. Ballistic testing by caliber $5.56 \times 45 \mathrm{~mm}$ deformed full metal jacket on a sample plate with each a thickness of $6 \mathrm{~mm}$ at a distance of $15 \mathrm{~m}$ with a normal angle of attack. The results of ballistic testing on both single plates are they can be pierced by a projectile. While for the layered plate, projectile can only penetrate the front side of the plate. The characteristic of each hole that is formed shows the difference caused by the level of hardness of the plate. On the rear part of the plate, a bulge appears because of an impact from the front side of the plate. In the Soft Plate appear high petals around the hole on the front side with the microstructure deformed on the crater walls. While the hard plate forms small petals on the back side and slightly deformed crater walls. The Soft plate is perforated due to deformation with petaling and fragmentation mechanism, while the hard plate is perforated due to plugging mechanism and adiabatic shear band and cracked.
\end{abstract}

Keywords

soft steel, hard steel, ballistic, crater

\section{Introduction}

Ballistic resistant materials (armor) are material that can withstand the pace of projectile fired from guns. It's developed and used in military or civil as the main construction and additional surface protection [1], and metallic armor is the most mature class of armor materials and is still widely used for ballistic protection today [2]. Armor material has long been developed and has been made to contour maps for ballistic performance of thick metallic armor as reported [3]. One of the constructions that require ballistic resistant material is Armored Fighting Vehicle (AFV) with main material of steel plate [4]. The success of AFV is predicated on the alignment of their capabilities with mission requirements [5], the mission can be chase, attack and defense. The more thickness of the plate in use then ballistic impact become higher, but causes the vehicle increasingly heavy, consequently declines the efficiency and agility as reported [6].

Ballistic resistant steel has been created and developed through quench temper and has been investigated in [7-9], bainitic quench temper in $[10,11]$ to improve the strength and hardness. The more hardness of the steel increases, then ballistic resistance increases up to a certain value will decreases and finally a failure occurs due to the process of shearing and cracked so perforated from ballistic impacts has been reported in [12]. Failure mechanism up to the perforated on the plate shapes brittle fracture, radial fracture, ductile hole growth, plugging, fragmentation and petaling has been reported [13], ductile hole formation, soft plugging, hard plugging and target shatter has been reported in [14]. Ballistic resistance of the steel is complex function from mechanical properties, such as yield strength, tensile strength, hardness, ductility and charpy. Only one of mechanical properties unable to be used to predict the ballistic resistance, an optimum combination of strength, hardness and toughness is essential for good ballistic performance [15]. Besides the hardness, the thickness of the steel plate also affects the ballistic impact as stated in $[8,9]$.

In the case of projectile impact against hard steel plate, it will form Adiabatic Shear Band (ASB) and makes the plate cracked, broken, and eventually perforated, 
as reported in [16]. The higher the material hardness, the easier the formation of ASB. Furthermore, the ASB triggers plugging as a result of shear stress [17]. As in [18] summarizes that ASB are formed in the process of dynamic deformation at a high strain rate, heat generated by the localized shear plastic deformation is hardly emitted outside due to lack of time, so the temperature rises suddenly in the local area. Heat on a narrow area and the acceleration of plastic deformation are main factor of the establishment of the band so that causes damage, has been reported [19]. ASB formation of high strength steel depends on the hardness, thickness and percentage of the hole made in the plate has been reported [9].

As in [20] reports performance of monolithic and double-layered shields against projectile impact with four types of projectiles of different weight and nose shape. The simulations with finite element prove that the double-layer configuration is able to improve the ballistic resistance by $8.0 \%-25.0 \%$ for the flat-nose projectile, compared to the monolithic plate of the same weight. Whereas conical-nose projectile does not indicates significant differences. As in [21] also reports that the best configuration double layered obtain the upper layer of high ductility and low strength material and the lower layer of low ductility and high strength material.

As in [22] has also been conducting experiments ballistic performance with blunt and ogival-nosed projectiles of double-layered steel plates of different materials. Result shows that the double-layered plates of the upper layer with high strength and low ductility material and the lower layer of low strength and high ductility have higher ballistic limit velocities than the configuration of the opposite layering order. The ogival-nosed projectiles are significantly smaller than those of blunt nosed projectiles ballistic limit velocities.

Study to compare monolithic with layered plate using several plates with the same total thickness and manufactured from the same material and different materials has been many reported. Construction of layered plates that are mutually made fixed/permanent resulted in the impact energy of the projectile will proceed directly to the next plate layer. So in this method has been presented manufacturing to one plate in front side that has the free (nonfixed/permanent) is slightly reported.

In this paper will describe and analyze the ability and the characteristics determine the ballistic characteristics of the two steel plates with different hardness levels and mix in the form of layered with manufacturing to one plate in front side that has the free (non-fixed/permanent) by macro and micro observation.

\section{Materials and methods}

\subsection{Sample preparation}

Steel plate of $6 \mathrm{~mm}$ thickness with different hardness was obtained from un-heat treatment steel for soft steel plate and heat treatment steel for hard steel plate. Heat treatment was carried out by austenitizing it at the temperature of 950 for $21 \mathrm{~min}$, followed by water spray quenching, and then tempered at the temperature of 250 for 21 min. Table 1 shows the chemical compositions of each steel plate and Table 2 shows the mechanical properties. Standard test method for Brinell hardness of metallic materials with ASTM E10, tension testing of metallic materials with ASTM E8, notched bar impact testing of metallic materials with ASTM E23.

\subsection{Ballistic testing}

Soft and hard plates were made for a panel $(150 \times 150 \mathrm{~mm})$ of ballistic test with single and double configuration shows in the Table 3. In the double configuration, soft plate was arranged on the back (back plate) with the aim of ease in manufacturing and application. The front plate is not fixed/permanently made on the back plate with a loose tab system. Each panel plate was shot at a distance of $15 \mathrm{~m}$ by using projectile caliber $5.56 \times 45 \mathrm{~mm} \mathrm{M}-193$ deformed full metal jacket with a normal attack angle (90 to the plate) in accordance with NIJ Standard 0108.01.

Table 1 Chemical composition of steel plate

\begin{tabular}{|c|c|c|c|c|c|c|}
\hline Material & \multicolumn{6}{|c|}{ Chemical Composition (\% wt.) } \\
\hline $\begin{array}{l}\text { Un-heat } \\
\text { treated steel } \\
\text { (soft plate) }\end{array}$ & \multicolumn{6}{|c|}{$\begin{array}{c}0.188 \% \mathrm{C}, 0.305 \% \mathrm{Mn}, 0.195 \% \mathrm{Si}, 0.013 \% \mathrm{P} \\
0.001 \% \mathrm{~S}, 0.009 \% \mathrm{Cu}, 0.016 \% \mathrm{Ni}, 0.042 \% \mathrm{Cr} \\
0.005 \% \mathrm{~V}, 0.002 \% \mathrm{Nb}, 0.029 \% \mathrm{Ti}, 0.012 \% \mathrm{Al} \\
0.003 \% \mathrm{Sn}, 0.005 \% \mathrm{~Pb}, 0.009 \% \mathrm{Zn}, 0.005 \% \mathrm{Co} \\
\text { balance Fe }\end{array}$} \\
\hline $\begin{array}{l}\text { heat treated } \\
\text { steel (hard } \\
\text { plate) }\end{array}$ & \multicolumn{6}{|c|}{$\begin{array}{c}0.246 \% \mathrm{C}, 1.349 \% \mathrm{Mn}, 0.375 \% \mathrm{Si}, 0.002 \% \mathrm{P} \\
0.037 \% \mathrm{Cu}, 0.252 \% \mathrm{Ni}, 0.242 \% \mathrm{Mo}, 0.743 \% \mathrm{Cr} \\
0.007 \% \mathrm{~V}, 0.007 \% \mathrm{Nb}, 0.004 \% \mathrm{Ti}, 0.047 \% \mathrm{Al}, \\
0.005 \% \mathrm{Sn}, 0.006 \% \mathrm{~Pb}, 0.016 \% \mathrm{Zn}, 0.003 \% \mathrm{Co}, \\
\text { balance Fe }\end{array}$} \\
\hline \multicolumn{7}{|c|}{ Table 2 Mechanical properties } \\
\hline Material & $\mathrm{BHN}$ & $\begin{array}{l}\text { Yield } \\
\text { Stress } \\
(\mathrm{MPa}) \\
\end{array}$ & $\begin{array}{c}\text { Max } \\
\text { Stress } \\
(\mathrm{MPa})\end{array}$ & $\begin{array}{c}\varepsilon \\
(\%)\end{array}$ & $\begin{array}{c}\text { Impact } \\
\text { Energy } \\
(\mathrm{J})\end{array}$ & $\begin{array}{c}K \\
\left(\mathrm{~J} / \mathrm{mm}^{2}\right)\end{array}$ \\
\hline $\begin{array}{l}\text { Un-heat } \\
\text { treated steel } \\
\text { (soft plate) }\end{array}$ & 118.21 & 331.85 & 458.16 & 31 & 62.48 & 1.25 \\
\hline $\begin{array}{l}\text { heat treated } \\
\text { steel (hard) }\end{array}$ & 478.23 & 1220.82 & 1466.19 & 13 & 47.77 & 0.95 \\
\hline
\end{tabular}


Table 3 Plate configurations

\begin{tabular}{|c|c|c|c|}
\hline Configuration & Geometry & Thickness & Code \\
\hline Soft plate & $>$ & $6 \mathrm{~mm}$ soft plate & $\mathrm{S}$ \\
\hline Hard plate & b & $6 \mathrm{~mm}$ hard plate & $\mathrm{H}$ \\
\hline Soft-soft plate & & $\begin{array}{c}6 \mathrm{~mm} \text { soft plate }-6 \mathrm{~mm} \text { back } \\
\text { plate }\end{array}$ & SS \\
\hline $\begin{array}{l}\text { Hard-soft } \\
\text { plate }\end{array}$ & & $\begin{array}{c}6 \mathrm{~mm} \text { hard plate }-6 \mathrm{~mm} \text { back } \\
\text { plate }\end{array}$ & HS \\
\hline
\end{tabular}

The average velocity projectiles were $989 \mathrm{~m} / \mathrm{s}$ measured with the chronograph Prochrono ${ }^{\circledR}$. The witness plats were made of aluminum sheet with a thickness of $0.2 \mathrm{~mm}$. Fig. 1 is the usage of scheme panel and shooting positions as well as the projectiles.

\subsection{Analyzed preparation}

The results of the tests were based on macro observation by using a macro camera and the micro samples were polished mechanically, and it was etched for $7 \mathrm{~s}$ with a $2 \%$ nital solution. Afterwards, this was observed and analyzed under the aid of a microscope optic.

\section{Results and discussion}

\subsection{Macro observation}

Projectiles can penetrate single soft and hard plate (S and $\mathrm{H}$ configuration) after ballistics tests and both formed craters. Craters characteristic that formed on both plates were different because it affected the level of hardness of each plate. Around the crater hole in the soft plate, formed petals on both sides which are the front face and back face of

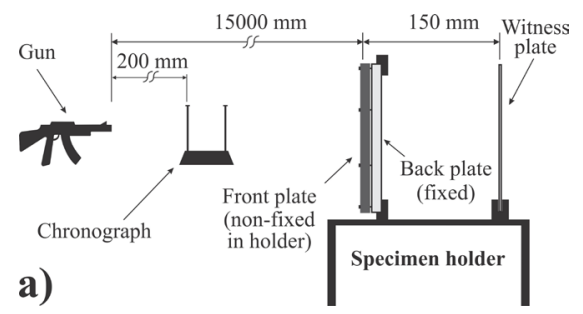

b)

Fig. 1 a) Ballistics testing schematic and b) projectile the projectile's direction. The hard plate did not appear petal but formed broken lips around the crater hole on the front face and petal with crack on the back face. Fig. 2 shows Macro observation on single soft plate $(\mathrm{S})$ and hard plates $(\mathrm{H})$.

The crater formed with a high petal on the front face due to plastic deformation soft plate as shown in the macro deformed around the petal (Fig. 2 a) front face). High velocity ogival/tapered-nosed projectile (Fig. 1 b)), so that the projectile can be easily pierced to a soft plate. Due to a puncture, then the plate was deformed to a round of the hole and formed a high petal on the front face. While on the rear face of the petals appeared small (Fig. 2 a) rear face) with a different shape from the front face. Petals on the rear face occurred due to former fault and deformation by projectile impact.

The petals were not formed on the front face of the hard plate due to the plate character of the hard, brittle and not easily deformed, so that the pointed projectile was not capable of piercing the plate (Fig. 2 b) front face). Petal formed irrespective because the plate was very brittle by projectile impact so that left the former fault around hole which were called broken lips. Piercing projectile when impact the surface of the plate, the projectile became blunt and due to the high thrust force, the plate can be broken up to penetrate the plate. The rear face plate formed petals with cracks that indicated the material were brittle and low ductility (Fig. 2 b) rear face).

Characters of the cross-section hole formed in the soft plate enlarged on the back face (Fig. 2 a) cross section) this was the case beside deformation also occurred fracture when the projectile inside the plate, and the fault was pushed to the back face. At the hard plate did not occur flakes so that the holes formed from the front face to the back were relatively similar (Fig. 2 b) cross section).

Fig. 3 shows plate fault due to projectile impact and hole formation in the witness plate on the single plate test. It proved that the soft plate besides occurred due to deformation also large fracture and small flake fracture that spread (Fig. 3 a) and Fig. 3 c)). The Crater formed beside due to projectiles puncture and deformation also due to the fracture on the plate on the back face (Fig. 3 a)). Fault plate and projectiles spread so that caused large hole and small holes around it on the witness plate (Fig. 3 c)).

The hard plate appeared single fracture was pushed to the back (Fig. 3 b)) the fault also appeared relatively flat, this proved that the projectile was not able to puncture plate but it projectile deformed be blunt. The single fracture penetrated the witness plate a form single hole (Fig. 3 d)). 


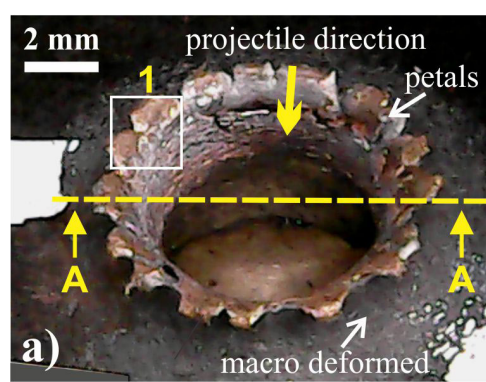

Front face

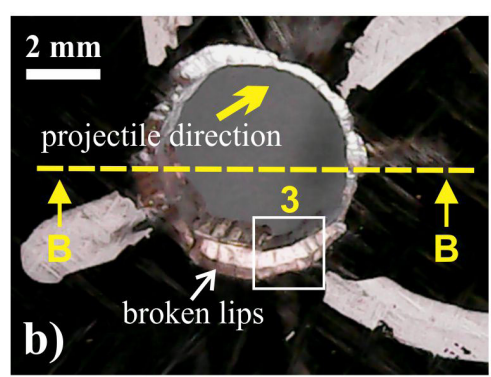

Front face

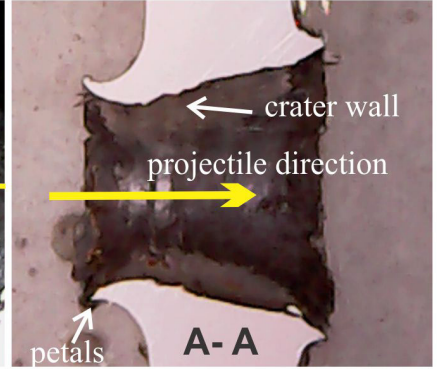

Cross section

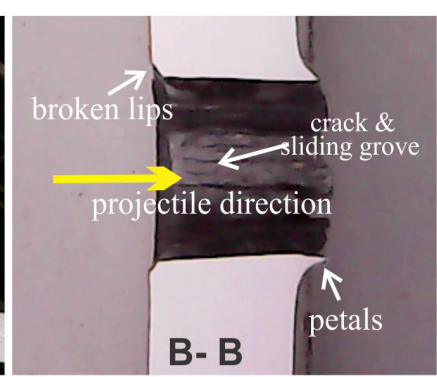

Cross section
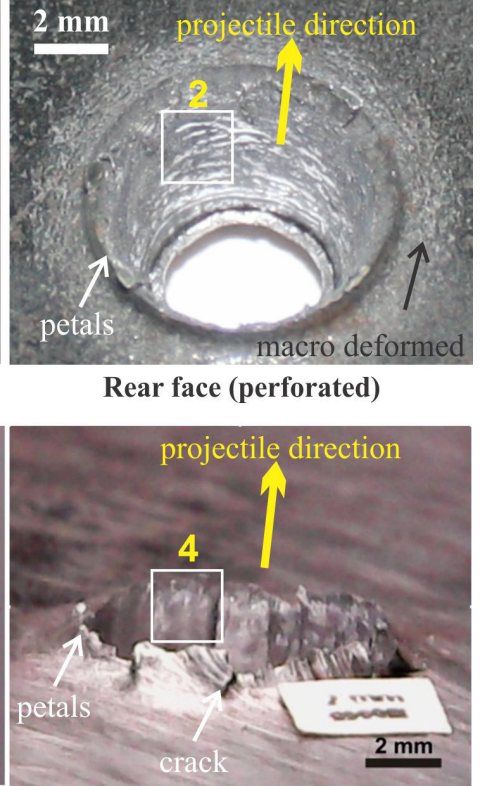

Rear face (perforated)

Fig. 2 Macro observation single soft and hard plate

Fig. 4 shows macro observation on the petals, broken lips and crater wall. The soft plate was produce hot roll forming layered petals with residual jacket attached to petals (Fig. 4 a)). Besides the deformation, the plate also broke from the projectile impact. Fracture occurred on the plate were ductile fracture was seen along the crater wall (Fig. 4 b)). Petals were not formed on a hard plate because fracture around the hole due to the brittle plate happened, thus formed a broken lip (Fig. 4 c)). Single fracture in a cylindrical shape pushed to the back face of the plate, to form a sliding groove on the crater wall (Fig. 4 d)).

In the double plate (SS configuration and configuration HS) obtained the ballistic test results as shown in Fig. 5. Crater formed on the front and back side of the front plate on soft and hard plate similar to the single plate.

On the SS configuration (Fig. 5 a)) were soft plate - back plate, the projectile had completely perforated the front plate. Front plate formed petals on the front face and inner side plate. The residual velocity of the projectile and plate spall was still able to push the back plate so it deformed. This deformation caused the back plate on the rear face to form a bulge. The dominant failure model of the front plate SS configuration were petalling and fragmentations, while on the back plate was bulging.

Meanwhile the sample with HS configuration (Fig. 5 b)) were hard plate - back plate, on the front face seen spalls on the crater lip and cylinder plugging shape were pushing back plate. High hardness and high strength plate were able to resist the velocity and broke the projectile tip better, although this hard plate had lower impact energy than the soft plate. The petals did not visible on the front face and slightly visible on the inner side. Plugging that are formed by the impact of projectiles able to push slight back plate and smooth bulge on the rear side of the back plate appeared. Failure model of the front plate in HS configuration was plugging which spall in lips crater on front face.

There were differences in the ballistic resistance between SS and HS configuration. On the SS configuration, projectile with an ogival/tapered-nosed (Fig. 1 b)) was able to stab plate and plate deformed so it formed a petal on the front and back face. As in [9], have described the same as formed petal and smooth crater on the low strength and high strain steel plate due to the high temperature tempering. The petal formed in the front and rear on the mild steel plate due $7.62 \mathrm{~mm}$ AP projectile through numerical simulations and experiments [23]. Low strength on the plate caused plate easily penetrated by a projectile although the high toughness and impact energy. Plate was unable to withstand projectiles at high velocity with an ogival/tapered-nosed. High strain on the plate caused the plate easily deformed thus formed petal on both the front face and back face in the first layer plate.

Furthermore, on the $\mathrm{H}$ configuration, the petals on the front face were not found. Hard material with high strength and low strain trends brittle. The projectiles cannot pierce plate. High velocity projectiles were causing fractures around the crater lip and then broken plate formed a cylinder plugging. Plugging mechanism occured because the end 


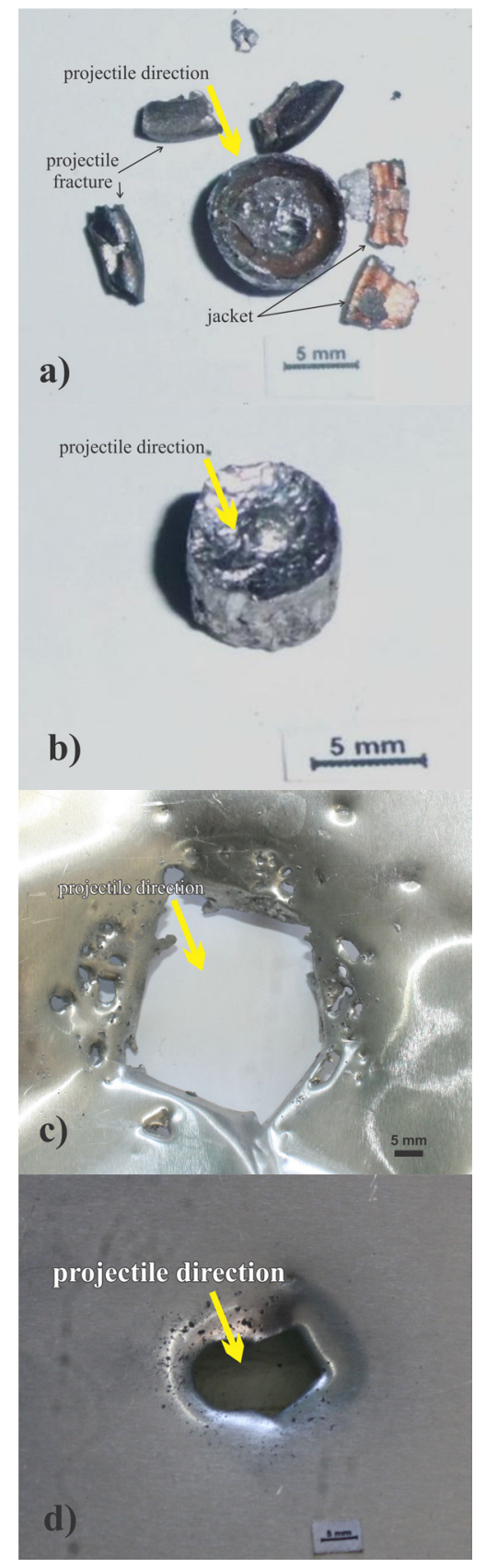

Fig. 3 Formation of fracture plat and hole witness plate. a) formation of fracture soft plate, b) formation of fracture hard plate, c) hole witness plate from soft plate and d) hole witness plate from hard plate.

of projectile was blunt due to impact. Projectile caused failure by plugging which involved shearing used hemispherical-nosed projectiles [24]. This plugging shape as formed in high strength armor steel $10 \mathrm{~mm}$ of thickness impacted by $7.62 \mathrm{~mm}$ deformable projectiles [15]. Real perforation did not appear in this configuration because the cylinder plugging restrained by the back plate. HS configuration (high strength, low strain) will significantly be a superior

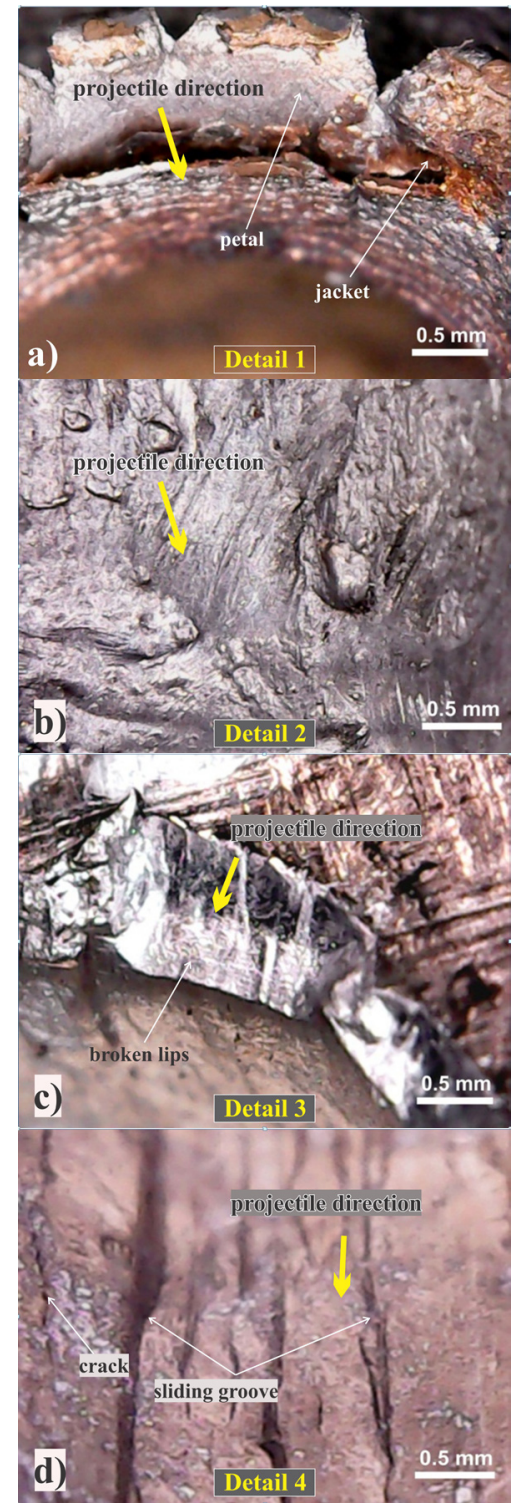

Fig. 4 Fracture formation on single soft and hard plate. a) petal in soft plate, b) crater wall in soft plate, c) broken lips in hard plate and d) crater wall in hard plate.

ballistic resistance than the $\mathrm{S}$ configuration because of its resistance capable of breaking the tip of the projectile. It has also been submitted in [25], where the high strength and low ductility material was Armox 560T of the upper layer, while the low strength and high ductility material was Weldox 700E to used blunt-nosed projectile [22] the target plates were made of 45 steel and Q235 steel used blunt and ogival-nosed projectile.

Crater hole diameter formed in the plate larger than the diameter of the projectile are used, it was due to plate occur plastic deformation during projectile impact at the high velocity. Table 4 shows the complete dimensions of craters formed. 


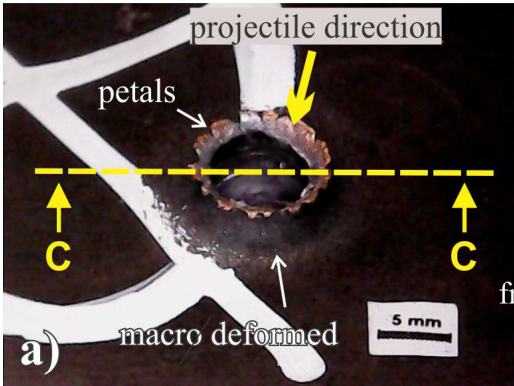

Front face

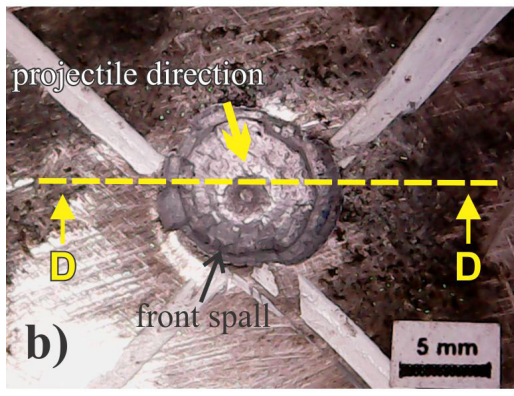

Front face

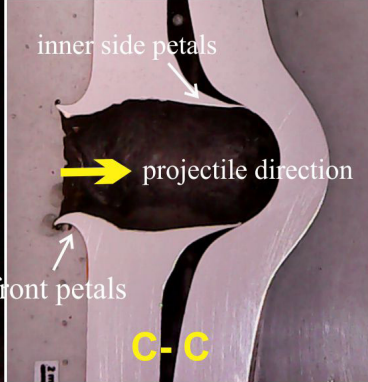

Cross section

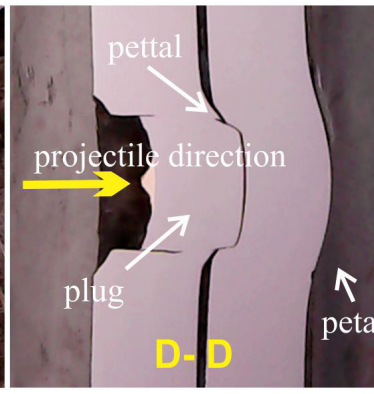

Cross section

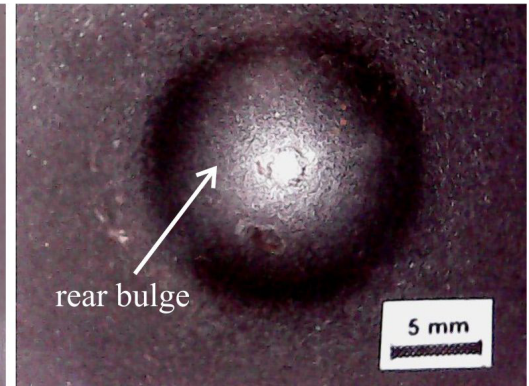

Rear face

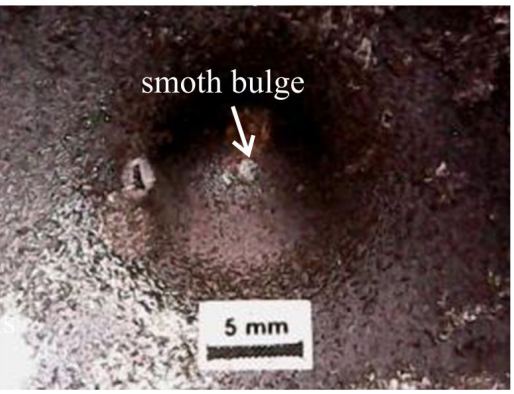

Rear face

Fig. 5 Front and rear impact area a) SS configuration and b) HS configuration

Table 4 Crater dimension front plate formed projectile impact $5.56 \times 45 \mathrm{~mm}$ caliber

\begin{tabular}{lcccccc}
\hline Configuration & $\begin{array}{c}\text { Hole diameter } \\
\text { front face }(\mathrm{mm})\end{array}$ & $\begin{array}{c}\text { High petal front } \\
\text { face }(\mathrm{mm})\end{array}$ & $\begin{array}{c}\text { Hole diameter } \\
\text { back face }(\mathrm{mm})\end{array}$ & $\begin{array}{c}\text { High petal back } \\
\text { face }(\mathrm{mm})\end{array}$ & $\begin{array}{c}\text { DoP back plate } \\
(\mathrm{mm})\end{array}$ & $\begin{array}{c}\text { High bulge back } \\
\text { plate }(\mathrm{mm})\end{array}$ \\
\hline Soft plate (S) & 6.26 & 3.99 & 9.46 & 1.46 & - & - \\
Hard plate (H) & 6.88 & - & 6.88 & 1.20 & - & - \\
Soft-soft plate (SS) & 7.08 & 2.44 & 7.80 & 7.08 & 6.02 & 6.10 \\
Hard-soft plate (HS) & 6.68 & - & - & 3.82 & 2.22 & 1.20 \\
\hline
\end{tabular}

The hole formed in the soft plate (S) formed a different diameter with diameter projectile used $6.26 \mathrm{~mm}$ and $5.56 \mathrm{~mm}$. Diameter that formed larger than the diameter of the projectile. This proved to occur of plastic deformation after projectile through the soft plate. Diameter on the backside much larger $(9.46 \mathrm{~mm})$ than the diameter on the front side as shown in cross-section holes are formed (Fig. 3 a)). The greater diameter on the back side was due to fracture in the plate when the projectile passed through the plate. This was evidenced in the witness plate (Fig. 4 c)) forming the main large hole and small holes around it. Large hole due to the projectile passed through a large plate and fracture, while small holes around the main hole showed projectile or plate fragments separated and penetrated the witness plate. Failure on the soft plate so that induced the formation of craters was a combination of process petaling and fragmentation reported in [13], which evidenced by the formation of petals and appear small fracture or soft plugging process as reported in [14] were the formation of holes with petals on the front side and then formed the main fracture driven by a projectile.
Crater hole diameter formed in the hard plate $(\mathrm{H})$ was $6.88 \mathrm{~mm}$ (Table 4), much larger than the projectile diameter of $5.56 \mathrm{~mm}$ was used. This was due to the deformed projectile while hitting the plate so that the projectile diameter was great before the perforation plate. Diameter formed on the front side and the back side of the same (Fig. 3 b)), and did not visible small pieces pushed to the back as evidenced in the witness plate was formed only a single hole (Fig. 4 d)). A large impact force cannot be detained by the hard plate so that the plate of failed and perforated with a plugging mechanism reported in [13] or hard plugging in [14]. Plugging is the formation of holes due to a single fracture and sliding, while hard plugging is hole formation due to fracture that shifted that are preceded the formation of a small fracture on the side face.

The character of the front plate hole on SS configuration was similar to the $\mathrm{S}$ configuration that was high petal formation with a large diameter hole. It was also due to the deformation of the plate due to prick of the projectile's tip. So did with the character of the hole on the front plate HS configuration was the same with a hole on the 
$\mathrm{H}$ configuration that was visible faults and plugging. The remained projectile energy that was absorbed at the front plate was still capable of forming a crater on the rear plate so as to form a crater, although did not penetrate (Depth of Penetration $=$ DoP). A bulge on the back side was visible either on the SS or SH configuration. A bulge on SH configuration. The Depth of Penetration (DoP) on a SS configuration plate was deeper than the HS configuration plate, as well as the bulge height on the SS configuration plate was higher than the $\mathrm{SH}$ configuration plate. This proved that the hard plate on the front side was better in resist ballistic pace compared with the soft plate.

\subsection{Micro observation}

Fig. 6 shows the microstructure on the soft plate, visible structure of ferrite and pearlite. Grains of Ferrite and pearlite in a fairly remote area of the crater wall appeared relatively round (Fig. 6 b)), while in the area close to the crater wall of the seen oval (Fig. 6 c)) with an oval shape in line with projectile direction. This formation due to deformation proses while projectile penetrates into the plate. It proved that perforated of soft plate occurs plastic deformation besides the fault occurred by projectile impact.

Fig. 7 shows martensitic structures on a hard plate as quench temper process. Martensitic structure both in areas far from the crater walls (Fig. 7 a)) and in the area near the crater walls (Fig. 7 b)) did not have a significant difference. This proved that no or little deformation structure on a hard plate. Therefore, the hole was not as dominated by deformation but due to a fault on a plate driven
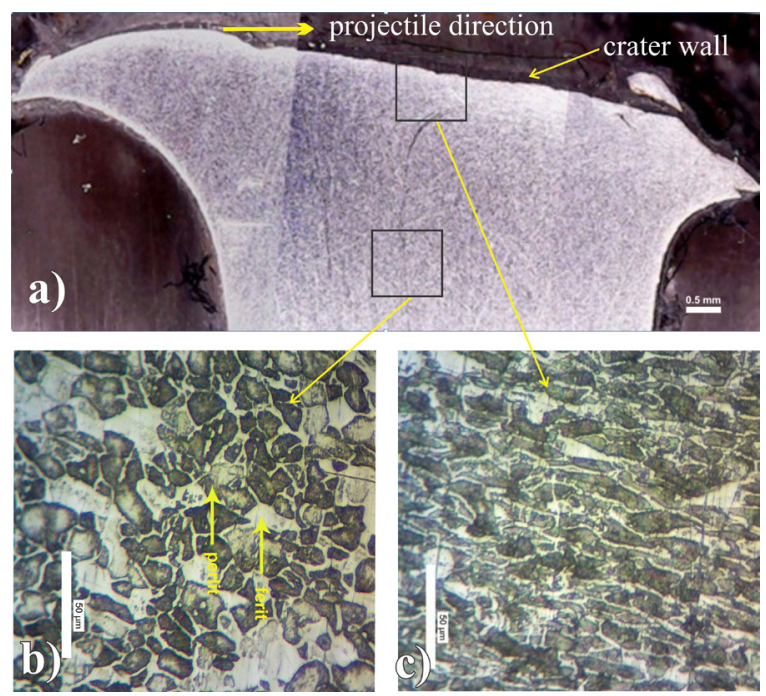

Fig. 6. Microstructure of soft plate.

a) the side of the ballistic testing, b) ferrite and pearlite structure normally away from hole projectile impact and c) ferrite and pearlite structure is deformed due to of the impact of a projectile by a projectile impact. Microstructure of hard plate show in Fig. 8, crack in hard plate show in Fig. 9 and ASB formation showed in Fig. 10.

Another area in the crater wall on the hard plate seen ASB (Fig. 8), crack (Fig. 9) and ASB induced cracking (Fig. 10) as has been reported in [9]. The ASB appeared due to high

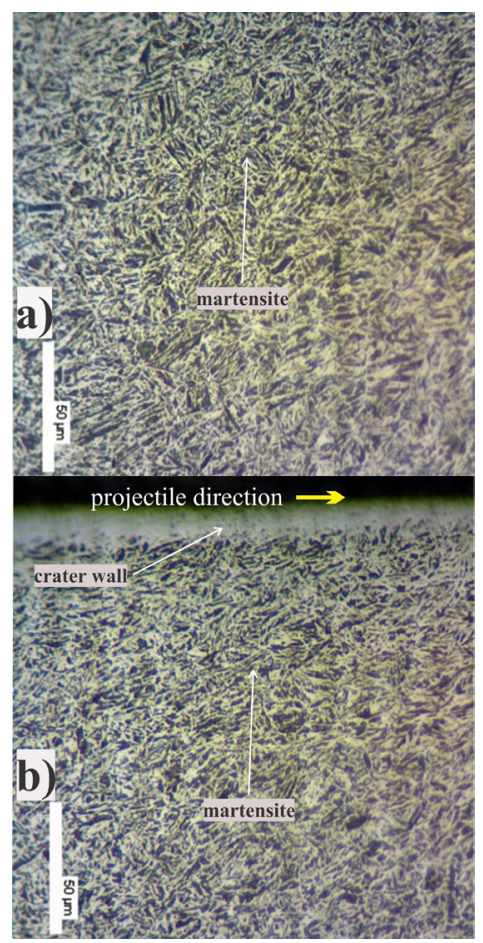

Fig. 7 Microstructure of hard plate.

a) the far side of hole projectile impact and b) the edge of the hole projectile impact
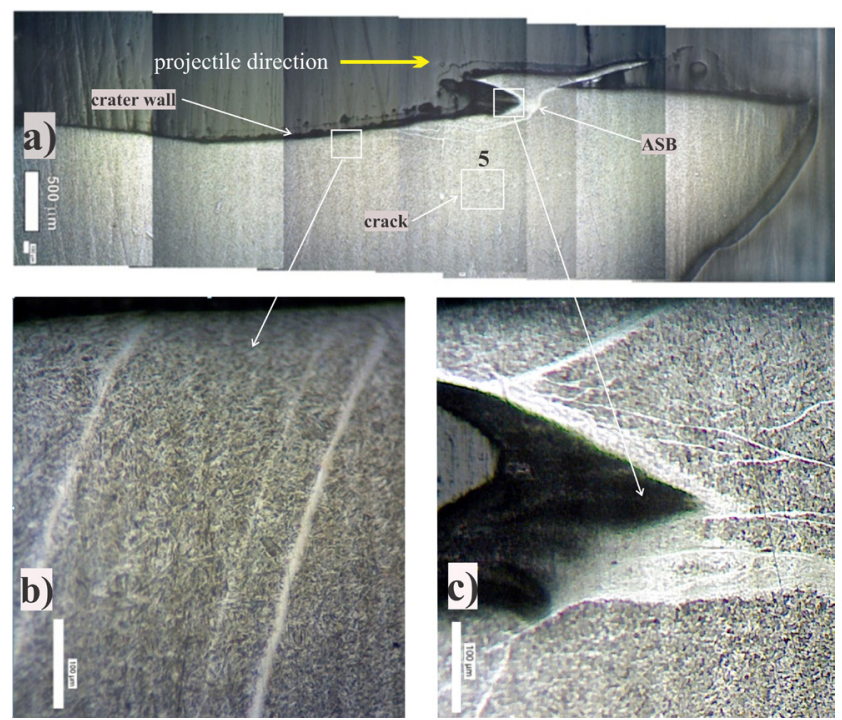

Fig. 8 Microstructure of hard plate.

a) crater hole ballistic impact, b) ASB on the holes edge curved to toward the rate of projectile and c) ASB which appears in the fracture 


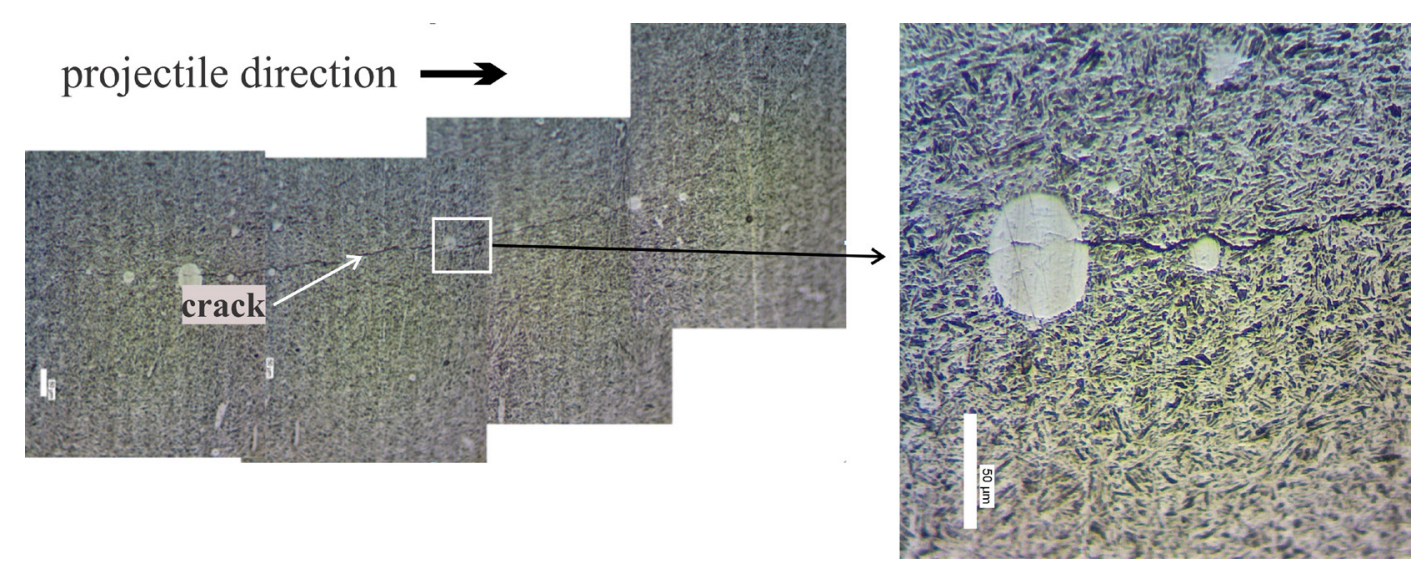

Fig. 9 Cracks in the plate hardened the direction of projectile rate (Detail 5)

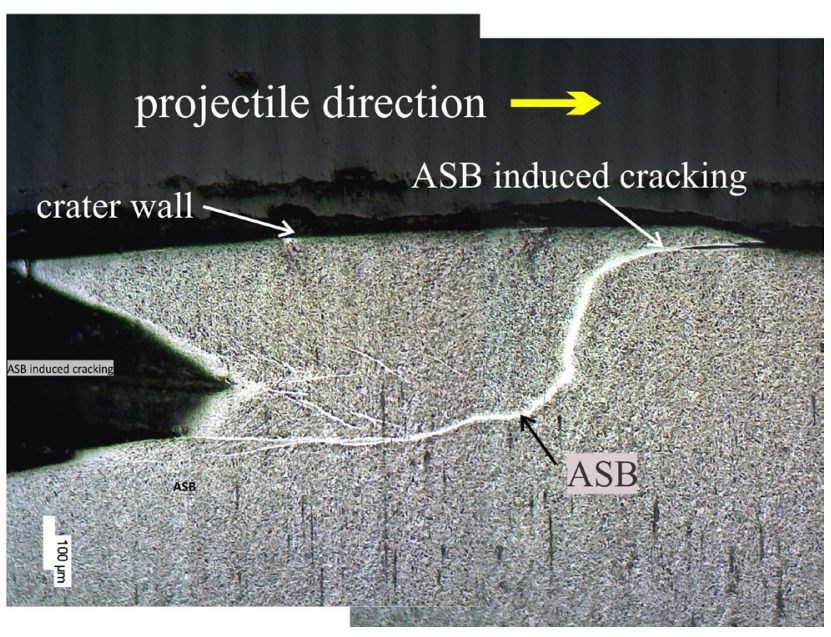

Fig. 10 ASB formation which causes the fracture

strain occured in the hard material so that the ASB did not appear clearly on the soft plate which easily deformed.

ASB formations with a curved shape with the arch direction the same of projectile direction seen in almost all the crater holes (Fig. 8 b)). ASB formation on the hard plate cause crack trigger along band and produced fracture. This showed before the fracture, hard palate which was impacted in weak areas will deform into a white band and then further cracked and broken [17]. ASB induced cracking formation (Fig. 8 c) and Fig. 10).

Cracks on the inside were also seen in hardened steel with an elongated shape in the direction of the rate of the projectile (Fig. 9). It did not found ASB around the crack, so the crack was not preceded by the formation of the band as it occurred in areas of direct contact with the projectile. Cracks were not appear on the soft plate that were ductile because soft plate easily deformed so that the impact energy when exposed to impact from projectiles.

\section{Conclusion}

The results of ballistic testing that used projectile caliber $5.56 \times 45 \mathrm{~mm}$ M-193 deformed full metal jacket with a distance of $15 \mathrm{~m}$ normal angle of attack on the soft plate hard plate and double plate with a non-fixed/permanent arrangement on the back plate can be concluded into.

The projectiles can penetrate both single plates while on double plate, only the front plate that is penetrable while the rear plate is formed a bulge.

At the soft plate both on single and double plate appears petal, on the front side due to punctured piercing projectile and plastics deformation. Perforations mechanism occur the fragmentation and petaling process.

The Bulge formed on the back plate caused by the remained projectile impact energy on the front plate. Bulge on soft plate composition on front side is greater than the composition of the hard plate on the front side, so that hard plate can resist projectile better than soft plate.

At the hard plate, the diameter crater hole formation is greater than the diameter of the projectile due to deformed projectile before penetrate plate, and hard plat was not occur plastic deformation. Perforations mechanism occur the plugging.

At the hard plate appears Adiabatic Shear Band and cracking due to projectile impact.

\section{Acknowledgement}

This work is the financed and supported by the Ministry of Research, Technology and Higher Education of the Republic of Indonesia. 


\section{References}

[1] Karagoez, S., Atapek, H., Yilmaz, A. "Microstructural Characterizaton and Effects on Mechanical Properties of Boron Added Armor Steels", The International Conference on Applied Mechanics and Mechanical Engineering, 13, pp. 50-62, 2008. https://doi.org/10.21608/amme.2008.39323

[2] Dimeski, D., Srebrenkoska, V. "The Role of Contemporary Ferrous and Nonferrous Materials in Ballistic Protection of Military Vehicles", In: VI ${ }^{\text {th }}$ International Metallurgical Congress, Ohrid, Macedonia, 2014. [online] Available at: http://eprints.ugd.edu. mk/10051/1/CONTEMPORARY\%20FERROUS.pdf [Accessed: 23 August 2015]

[3] Srivathsa, B., Ramakrishnan, N. "Ballistic performance maps for thick metallic armour", Journal of Materials Processing Technology, 96(1-3), pp. 81-91, 1999. https://doi.org/10.1016/S0924-0136(99)00270-8

[4] Kılıç, N., Ekici, B. "Ballistic resistance of high hardness armor steels against $7.62 \mathrm{~mm}$ armor piercing ammunition", Materials \& Design, 44, pp. 35-48, 2013. https://doi.org/10.1016/j.matdes.2012.07.045

[5] United States National Research Council "Application of Lightweighting Technology to Military Aircraft, Vessels, and Vehicles", The National Academies Press, Washington, DC, USA, 2012 https://doi.org/10.17226/13277

[6] Rose, D. H. "Editorial: Adapting to a Changing Battlefield", Amptiac, 8(4), 2004. [online] Available at: http://citeseerx.ist.psu. edu/viewdoc/download?doi=10.1.1.383.9330\&rep=rep1\&type=pdf [Accessed: 27 November 2015]

[7] Maweja, K., Stumpf, W., van der Berg, N. "Characteristics of martensite as a function of the $M_{s}$ temperature in low-carbon armour steel plates", Materials Science and Engineering: A, 519(1-2), pp. 121-127, 2009.

https://doi.org/10.1016/j.msea.2009.04.061

[8] Jena, P. K., Mishra, B., Siva Kumar, K., Bhat, T. B. "An experimental study on the ballistic impact behavior of some metallic armour materials against $7.62 \mathrm{~mm}$ deformable projectile", Materials \& Design, 31(7), pp. 3308-3316, 2010. https://doi.org/10.1016/j.matdes.2010.02.005

[9] Mishra, B., Jena, P. K., Ramakrishna, B., Madhu, V., Bhat, T. B., Gupta, N. K. "Effect of tempering temperature, plate thickness and presence of holes on ballistic impact behavior and ASB formation of a high strength steel", International Journal of Impact Engineering, 44, pp. 17-28, 2012.

https://doi.org/10.1016/j.ijimpeng.2011.12.004

[10] Atapek, S. H., Karagoz, S. "Ballistic Impact Behaviour of a Tempered Bainitic Steel Against $7.62 \mathrm{~mm}$ Armour Piercing Projectile", Defence Science Journal, 61(1), pp. 81-87, 2011. https://doi.org/10.14429/dsj.61.411

[11] Martis, C. J., Putatunda, S. K., Boileau, J., Spray, J. G. "The static and dynamic mechanical properties of a new low-carbon, low-alloy austempered steel", Materials Science and Engineering: A, 589, pp. 280-287, 2014.

https://doi.org/10.1016/j.msea.2013.09.085
[12] Dikshit, S. N., Kutumbarao, V. V., Sundararajan, G. "The influence of plate hardness on the ballistic penetration of thick steel plates", International Journal of Impact Engineering, 16(2), pp. 293-320, 1995. https://doi.org/10.1016/0734-743X(94)00041-T

[13] Zukas, J. A. "Impact Dynamics: Theory and Experiment", U.S. Army Ballistic Research Laboratory, Aberdeen Proving Ground, MD, USA, Rep. ARBRL-TR-02271, 1980. [online] Available at: www.dtic.mil/dtic/tr/fulltext/u2/a093502.pdf [Accessed: 20 August 2020]

[14] Karagoez, S., Atapek, H., Yilmaz, A. "A Fractographical Study on Boron Added Armor Steel Developed by Alloying and Heat Treatment to Understand Its Ballistic Performance", The International Conference on Applied Mechanics and Mechanical Engineering, 13, pp. 63-76, 2008.

https://doi.org/10.21608/amme.2008.39319

[15] Jena, P. K., Mishra, B., RameshBabu, M., Babu, A., Singh, A. K., SivaKumar, K., Bhat, T. B. "Effect of heat treatment on mechanical and ballistic properties of a high strength armour steel", International Journal of Impact Engineering, 37(3), pp. 242-249, 2010.

https://doi.org/10.1016/j.ijimpeng.2009.09.003

[16] Staker, M. R. "The relation between adiabatic shear instability strain and material properties", Acta Metallurgica, 29(4), pp. 683-689, 1981. https://doi.org/10.1016/0001-6160(81)90151-6

[17] Bandanadjaja, B., Basuki, A., Siswosuwarno, M. "Perilaku Balistik Baja Komersial Scr 440 dengan Kekerasan Berlapis (Dual Hardness) dalam Simulasi dan Eksperimen" (Ballistic Behavior on Scr 440 Commercial Steel with Dual Hardness in Simulation and Experiment), Prosiding Seminar Nasional Teknoin, pp. A-31 - A-36, 2008. [online] Available at: https://journal.uii.ac.id/Teknoin/article/view/133/96 [Accessed: 01 May 2014] (in Indonesian)

[18] Kim, D.-K., Lee, S., Hyung Baek, W. "Microstructural study of adiabatic shear bands formed by high-speed impact in a tungsten heavy alloy penetrator", Materials Science and Engineering: A, 249(1-2), pp. 197-205, 1998. https://doi.org/10.1016/S0921-5093(98)00565-6

[19] Cho, K., Chi, Y. C., Duffy, J. "Microscopic observations of adiabatic shear bands in three different steels", Metallurgical Transactions A, 21(5), pp. 1161-1175, 1990. https://doi.org/10.1007/BF02698247

[20] Teng, X., Dey, S., Børvik, T., Wierzbicki, T. "Protection performance of double-layered metal shields against projectile impact", Journal of Mechanics of Materials and Structures, 2(7), pp. 1309-1330, 2007. https://doi.org/10.2140/jomms.2007.2.1309

[21] Teng, X. Wierzbicki, X. Huang, M. "Ballistic resistance of double-layered armor plates", International Journal of Impact Engineering, 35(8), pp. 870-884, 2008. https://doi.org/10.1016/j.ijimpeng.2008.01.008 
[22] Yunfei, D., Wei, Z., Yonggang, Y., Lizhong, S., Gang, W., "Experimental investigation on the ballistic performance of double-layered plates subjected to impact by projectile of high strength", International Journal of Impact Engineering, 70, pp. 38-49, 2014.

https://doi.org/10.1016/j.ijimpeng.2014.03.003

[23] Iqbal, M. A., Senthil, K., Bhargava, P., Gupta, N. K. "The characterization and ballistic evaluation of mild steel", International Journal of Impact Engineering, 78, pp. 98-113, 2015.

https://doi.org/10.1016/j.ijimpeng.2014.12.006
[24] Deng, Y., Zhang, W., Cao, Z. "Experimental investigation on the ballistic resistance of monolithic and multi-layered plates against hemispherical-nosed projectiles impact", Materials \& Design, 41, pp. 266-281, 2012.

https://doi.org/10.1016/j.matdes.2012.05.021

[25] Børvik, T. Hopperstad, O. S., Langseth, M., Malo, K. A. "Effect of target thickness in blunt projectile penetration of Weldox $460 \mathrm{E}$ steel plates", International Journal of Impact Engineering, 28(4), pp. 413-464, 2003.

https://doi.org/10.1016/S0734-743X(02)00072-6 